\title{
PELAKSANAAN PENGUATAN PENDIDIKAN KARAKTER MEMBENTUK KARAKTER CINTA TANAH AIR
}

\author{
Nur Tri Atika ${ }^{1}$, Husni Wakhuyudin ${ }^{2}$, Khusnul Fajriyah $^{3}$ \\ 1,2,3 PGSD Fakultas IImu Pendidikan Universitas PGRI Semarang \\ e-mail: Nurtriatika88@gmail.com ${ }^{1}$, Husni@gamil.com $^{2}$, Khususfajriyah@gmail.com $^{3}$
}

\begin{abstract}
Abstrak
Pendidikan karakter terutama karakter cinta tanah air harus diimplementasikan sejak dini, salah satunya melalui lembaga pendidikan. Penelitian ini untuk melihat dan mengungkapkan kegiatan Penguatan Pendidikan Karakter dapat menumbuhkan karakter cinta tanah air. Penelitian ini bertujuan mendeskripsikan bagaimana pembentukan karakter cinta tanah air melalui kegiatan Penguatan Pendidikan Karakter di SDN Pandean Lamper 04 Semarang. Jenis penelitian yang digunakan yaitu metode kualitatif dengan pendekatan deskriptif. Responden dari penelitian ini yaitu siswa kelas V SDN Pandean Lamper 04 Semarang. Terdapat 5 Indikator yang ada didalam karakter nasionalisme atau cinta tanah air dengan hasil tertinggi persentase sebesar $96 \%$. Dapat disimpulkan bahwa karakter cinta tanah air yang ditunjukkan oleh siswa kelas V SDN Pandean Lamper 04 Semarang sudah mengalami peningkatan hal ini dapat dilihat dari perkembangan karakter siswa yang sudah meningkat lebih baik.
\end{abstract}

Kata kunci : Penguatan Pendidikan Karakter, Cinta Tanah Air

\begin{abstract}
Character education, especially the character of nationalism, must be implemented early, through educational institutions. This research is to see and reveal Character Education activities can foster the character of nationalism. This study aims to describe how the character of nationalism is formed through Character Education activities at Pandean Lamper 04 Elementary School Semarang. The type of research is a qualitative method with a descriptive approach. Respondents from this study were fifth grade students of Pandean Lamper 04 Elementary School Semarang. There are 5 indicators are in the character of nationalism with the highest percentage of $96 \%$. It can be concluded that the character of nationalism shown by the fifth grade students of Pandean Lamper 04 Elementary School Semarang who experienced and increased. It can be seen from the character development of students who have improved better.

Keywords : Forming Character Education, Nationalism
\end{abstract}

\section{Pendahuluan}

Runtuhnya nilai moral di kehidupan masyarakat saat ini juga berdampak buruk pada nilai dan sikap anak pada saat ini. Hal ini disebabkan dari beberapa faktor yang mempengaruhi juga, salah satu faktor yang paling kuat adalah penggunaan gadget pada anak usia sekolah dasar. Dimana mereka mudah sekali terpengaruh dalam perkembangan tren dan sosialisasi yang ada di media sosial. Sehingga pihak orang tua harus ekstra dalam mendidik anak di rumah. Turunnya etika dan moral ini juga membuat sekolah harus bekerja sangat keras dalam mendidik dan menyampaikan ilmu pengetahuan kepada para peserta didiknya. Salah satu cara memperbaiki kemerosotan moral ini adalah dengan menggunakan pendidikan karakter yang tak hanya di rumah, namun juga secara terstruktur di sekolah. Permasalahan ini memicu pemerintah Indonesia harus memperbaiki hal tersebut,yang dimulai dari penanaman nilai-nilai/ norma-norma bangsa Indonesia terutama didalam lembaga pendidikan.

Menurut undang-undang dasar sistem pendidikan nasional No. 20 Tahun 2003 pasal 1 menjelaskan bahwa : "Pendidikan adalah usaha sadar dan terencana untuk mewujudkan suasana belajar dan proses pembelajaran secara aktif mengembangkan potensi dirinya untuk memiliki kekuatan spritual keagamaan mengendalikan diri kepribadian kecerdasan akhlak 
mulia serta keterampilan yang diperlukan drinya, masyarakat, bangsa, dan negara". Pembangunan karakter dan pendidikan karakter menjadi suatu keharusan karena pendidikan tidak hanya menjadikan peserta didik menjadi cerdas, juga mempunyai budi pekerti dan sopan santun, sehingga keberadaannya sebagai anggota masyarakat menjadi bermakna baik bagi dirinya maupun orang lain. Pembinaan karakter yang termudah dilakukan adalah ketika anakanak masih duduk di bangku sekolah dasar. Itulah sebabnya pemerintah memprioritaskan pendidikan karakter di SD. Bukan berarti pada jenjang pendidikan lainnya tidak mendapat perhatian namun porsinya saja yang berbeda (Mendiknas, 2010).

Upaya pembentukan karakter memiliki makna lebih tinggi dari pembentukan moral, karena pembentukan karakter tidak hanya berkaitan dengan masalah benar-salah, tetapi bagaimana menanamkan kebiasaan tentang hal-hal yang baik dalam kehidupan, sehingga anak atau peserta didik memiliki kesadaran dan pemahaman yang tinggi, serta kepedulian dan komitmen untuk menerapkan kebajikan dalam kehidupan sehari-hari. Pendidikan nasional berfungsi mengembangkan kemampuan dan membentuk karakter serta peradaban bangsa yang bermartabat dalam rangka mencerdaskan kehidupan bangsa, bertujuan untuk berkembangnya potensi peserta didik agar menjadi manusia yang beriman dan bertakwa kepada Tuhan Yang Maha Ea, berakhlak mulia, sehat, berilmu, cakap, kreatif, mandiri, dan menjadi warga negara yang demokratis serta bertanggung jawab (UU No. 2003 pasal 3).

Azyumardi Azra dalam (Rohinah M. Noor, Ma 2012:30) menyatakan bahwa pendidikan merupakan suatu proses di mana suatu bangsa mempersiapkan generasi mudanya untuk menjalankan kehidupan dan untuk memenuhi tujuan hidup secara efektif dan efisien. Bahkan ia menegaskan bahwa pendidikan lebih dari sekedar pengajaran. Artinya, pendidikan adalah suatu proses di mana suatu bangsa atau negara membina dan mengembangkan kesadaran diri di antara individu-individu.

Suyanto (2010) dalam Wibowo (2012: 33) menyatakan bahwa karakter adalah cara berpikir dan berperilaku yang menjadi ciri khas tiap individu untuk hidup dan bekerja sama, baik dalam lingkup keluarga, masyarakat, bangsa dan negara. Guru memegang peran yang sangat strategis terutama dalam membentuk karakter serta mengembangkan potensi siswa, begitu pentingnya peran guru dalam keberhasilan pelaksanaan pendidikan karakter disekolah, maka hendaknya guru mampu beradaptasi dengan berbagai perkembangan yang ada dan meningkatkan kompetensinya.

Pendidikan Karakter berfungsi (1) mengembangkan potensi dasar agar berhati baik, berpikir baik, dan berperilaku baik; (2) memeperkuat dan membangun perilaku bangsa yang multikultur; (3) meningkatkan peradaban bangsa yang kompetitif dalam pergaulan dunia. Pendidikan karakter dilakukan melalui berbagai media yang mencakup keluarga, satuan pendidikan, masyarakat sipil, pemerintah dan media massa. Pendidikan Karakter pada intinya bertujuan membentuk bangsa yang tangguh, kompetitif, berkembang dinamis, berorientasi ilmu pengetahuan dan teknologi yang semua dijiwai oleh iman dan taqwa kepada Tuhan Yang Mahan Esa berdasarkan Pancasila (Daryanto, 2013:45).

Azwar dalam (Silvya Eka Andiarini, Imron Arifin, dan Ahmad Nurabadi 2018: 238-239) menyatakan bahwa Salah satu upaya pemerintah tentang pendidikan karakter adalah Penguatan Pendidikan Karakter (PPK) yang terintegrasi dalam Gerakan Nasional Revolusi Mental, yaitu perubahan cara berpikir, bersikap dan bertindak menjadi lebih baik.

Salah satu upaya pemerintah tentang pendidikan karakter adalah Penguatan Pendidikan Karakter (PPK) yang terintegrasi dalam Gerakan Nasional Revolusi Mental, yaitu perubahan cara berpikir, bersikap dan bertindak menjadi lebih baik. Salah satu nilai positif yang perlu ditanamkan kepada peserta didik di sekolah adalah karakter cinta tanah air. Mengingat kenyataan yang ada saat ini banyak di kalangan generasi muda yang sudah mulai luntur rasa cinta tanah air. Rendahnya rasa cinta tanah air di tunjukan dengan adanya kenyataan di lapangan bahwa peserta didik yang datang terlambat saat mengikuti upacara, kurangnya penghayatan peserta didik ketika upacara bendera, lagu nasional maupun lagu daerah kurang disukai, sementara peserta didik lebih senang lagu orang dewasa yang belum pantas dimengeti dan dipahami untuk anak seusia mereka. Apabila kondisi ini dibiarkan maka 
dikhawatirkan peserta didik tidak mengenal bangsa Indonesia dan segala kekayaan budayanya yang dapat berimbas pada kurangnya sikap cinta tanah air pada peserta didik.

Salah satu nilai positif yang perlu ditanamkan kepada peserta didik di sekolah adalah karakter cinta tanah air. Mengingat kenyataan yang ada saat ini banyak di kalangan generasi muda yang sudah mulai luntur rasa cinta tanah air. Rendahnya rasa cinta tanah air di tunjukan dengan adanya kenyataan di lapangan bahwa peserta didik yang datang terlambat saat mengikuti upacara, kurangnya penghayatan peserta didik ketika upacara bendera, lagu nasional maupun lagu daerah kurang disukai, sementara peserta didik lebih senang lagu orang dewasa yang belum pantas dimengeti dan dipahami untuk anak seusia mereka. Apabila kondisi ini dibiarkan maka dikhawatirkan peserta didik tidak mengenal bangsa Indonesia dan segala kekayaan budayanya yang dapat berimbas pada kurangnya sikap cinta tanah air pada peserta didik.

Rendahnya nilai-nilai cinta tanah air tersebut karena pengaruh negatif budaya barat yang masuk di Indonesia. Nilai- nilai cinta tanah air perlu ditanamkan sejak dini agar sebagai penerus bangsa dapat mewujudkan sikap dan tingkah laku yang bermanfaat bagi kepentingan masyarakat. Pihak sekolah terutama guru diharapkan dapat mencari cara untuk meningkatkan rasa cinta tanah air agar peserta didik memiliki akhlak mulia, sehat, cerdas, keterampilan, perprestasi dan berdaya saing memiliki komitmen untuk memjukan bangsa.

Pelaksanaan pendidikan karakter (PPK) merupakan gerakan yang mampu meningkatkan karakter tiap individu agar memiliki karakter yang lebih baik oleh sebab itu keterlibatan orang tua, sekolah, dan masyarakat merupakan sebuah Gerakan Nasional Revoluis Mental masa depan bangsa. Kegiatan PPK sangat efektif untuk pembentukannya karakter peserta didik dan jika dilakukan berulang-ulang secara rutin hingga menjadi suatu kebiasaan, yang akhirnya tidak hanya suatu kebiasaan saja tetapi sudah menjadi suatu karakter.

Berdasarkan uraian diatas penulis mengambil judul "Kegiatan Penguatan Pendidikan Karakter (PPK) Membentuk Karakter Cinta Tanah Air Dalam Pada Siswa SDN Pandean Lamper 04 Semarang"

Berdasarkan rumusan masalah diatas, maka tujuan penulisan artikel ini adalah untuk mendeskripsikan pembentukan karakter cinta tanah air dalam kegiatan Penguatan Pendidikan Karakter (PPK) pada kelas V Sekolah Dasar.

Yaumi (2010) dalam Daryanto (2013: 9) bahwa karakter menggambarkan kualitas moral seseorang yang tercermin dari segala tingkah lakunya yang mengandung unsur keberanian, ketabahan, kejujuran, dan kesetiaan, atau perilaku dan kebiasaan yang baik. Karakter ini dapat berubah akibat pengaruh lingkungan, oleh karena itu perlu usaha membangun karakter dan menjaganya agar tidak terpengaruh oleh hal-hal yang menyesatkan dan menjerumuskan.

Berdasarkan beberapa pendapat, dapat disimpulkan bahwa karakter merupakan watak, sifat, akhlak ataupun kepribadian yang membedakan seorang individu dengan individu lainnya. Atau karakter dapat dikatakan juga sebagai keadaan yang sebenarnya dari dalam diri seorang individu, yang membedakan antara dirinya dengan individu lain.

Daryanto (2013: 64) menyatakan bahwa pendidikan karakter merupakan berbagai usaha yang dilakukan oleh para personil sekolah, bahkan yang dilakukan bersama-sama dengan orang tua dan anggota masyarakat untuk membantu anak-anak dan remaja agar menjadi atau memiliki sifat peduli, berpendirian, dan beratnggung jawab. Ratna Megawangi (dalam Dharma Kesuma 2013: 5) pendidikan karakter merupakan sebuah usaha untuk mendidik anak-anak agar dapat mengambil keputusan dengan bijak dan mempraktikkannya dalam kehidupan sehari-hari, sehingga mereka dapat memberikan konstribusi yang positif kepada lingkungannya. Berdasarkan beberapa pendapat diatas dapat disimpulkan bahwa pendidikan karakter merupakan kunci yang snagat penting di dalam membentuk kepribadian anak. Selain di rumah, pendidikan karakter juga perlu diterapkan di sekolah dan lingkungan sosial. Pada hakikatnya, pendidikan memiliki tujuan untuk membantu manusia menjadi cerdas dan tumbuh menjadi insan yang baik.

Lickona dalam (Daryanto 2013: 64) ada tujuh alasan mengapa pendidikan karakter itu harus disampaikan; (1) Merupakan cara terbaik untuk menjamin anak-anak (siswa) memiliki kepribadian yang baik dalam kehidupannya; (2) Merupakan cara untuk meningkatkan prestasi 
akademik; (3) Sebagian siswa tidak dapat membentuk karakter yang kuat bagi dirinya ditempat lain; (4) Mempersiapkan siswa untuk menghormati pihak atau orang lain dan dapat hidup alam masyarakat yang beragam; (5) Berangkat dari akar masalah yang berkaitan dengan problem moral sosial, seperti ketidaksopanan, ketidakjujuran, kekerasan, pelanggaran kegiaran seksual, dan etos kerja (belajar) yang rendah; (6) Merupakan persiapan terbaik untuk menyongsong perilaku di tempat kerja; (8) Mengajarkan nilai-nilai budaya merupakan bagian dari kerja peradaban.

Mulyana (2011: 9-10) menyatakan bahwa pada umunya pendidikan karakter menekankan pada keteladanan, penciptaan lingkungan dan pembiasaan, melalui berbagai tuga keilmuan dan kegiatan kondusif. Dengan demikian, apa yang dilihat, didengar, dirasakan dan dikerjakkan oleh peserta didik dapat membentuk karakter mereka. Selain menjadikan keteladanan dan pembiasaan sebagai metode pendidikan utama, penciptaan iklim dan budaya serta lingkungan yang kondusif juga sangat penting, dan turut membentuk karakter peserta didik. Penciptaan lingkungan kondusif dapat dilakukan melalui berbagai variasi metode sebagai berikut; (1) penugasan; (2) pembiasaan; (3) pelatihan; (4) pembelajaran; (5) pengarahan; dan (6) keteladanan.

Tujuan Pendidikan karakter adalah penanaman nilai dalam diri siswa dan pembaharuan tata kehidupan bersama yang lebih menghargai kebebasan individu dan juga bertujuan meningkatkan mutu penyelenggara dan hasil pendidikan di sekolah yang mengarahkan pada pencapaian pembentukan karakter dan akhlak mulia peserta didik secara utuh, terpadu, dan seimbang sesuai dengan standar kompetensi lulusan. Melalui pendidikan karakter, diharapkan peserta didik mampu secara mandiri meningkatkan dan menggunakan pengetahuannya, mengkaji dan menginternalisasi serta mempersonalisasi nilai-nilai karakter dan akhlak mulia sehingga terwujud dalam perilaku sehari-hari.

Cinta Tanah Air adalah perilaku yang menunjukan kepedulian, penghargaan, yang dilandasi semangat kebangsaan dan rela berkorban demi nusa dan bangsa. Perilaku sikap cinta tanah air berarti mencintai produk dalam negeri, rajin belajar bagi kemajuan bangsa dan Negara, mencintai lingkungan hidup, melaksanakan hidup bersih dan sehat, mengenal wilayah tanah air tanpa fanatisme kedaerahan. Sikap cinta tanah air tiap individu dapat tercemin melalui perilaku kehidupannya sehari-hari. Di Indonesia anak-anak diwajibkan untuk menempuh pendidikan, karena melalui pendidikan peserta didik dikenalkan dan diajarkan untuk mengenal dan mencintai Negaranya Indonesia. Cinta tanah air sama halnya cinta dengan lingkungan dimana kita tinggal. Meyakini bahwa Pancasila sebagai dasar Negara dan mengimplementasikannya dalam keseharian.

Mustari (2017: 160) mengemukakan pendapat yang menjadi indikator bahwa ciri-ciri menjadi nasionalis atau cinta tanah diantaranya yaitu Menghargai jasa para tokoh/pahlawan nasional; bersedia menggunakan produk dalam negeri; menghargai keindahan alam dan budaya Indonesia; hafal lagu-lagu kebangsaan; memilih berwisata dalam negeri.

Astutik dalam (Subadar 2017: 83-84) Penguatan Pendidikan Karakter (PPK) merupakan bagian pendidikan di sekolah untuk memperkuat karakter siswa. Bagian pendidikan yang dimaksud adalah keselarasan etika, estetika, literasi, dan kinestetik. hal ini tentunya tak lepas dari dukungan dan keterlibatan publik serta kerjasama antara sekolah, keluarga, dan masyarakat. Perwujudan karakter individu yang berasal dari hasil integrasi empat bagian karakter bangsa yang sesuai prinsip pancasila dikembangkan dari buku Desain Induk Pembangunan Karakter Bangsa 2010-2025 (Pemerintah Republik Indonesia, 2010), antara lain: pertama, olah hati yaitu beriman dan bertakwa, bersyukur, jujur, amanah, adil, tetib, sabar, disiplin, taat aturan, bertanggungjawab, berempati, punya rasa iba, berani mengambil resiko, pantang menyerah, menghargai lingkungan, rela berkorban, dan berjiwa patriotik. Kedua, olah pikir yaitu cerdas, kritis, kreatif, inovatif, analitis, ingin tahu, produktif, berorientasi IPTEKS, dan reflektif. Ketiga, olah rasa yaitu kemanusiaan, saling menghargai, saling mengasihi, kerjasama, kebersamaan, ramah, peduli, hormat, toleran, nasionalis, komopolit, mengutamakan kepentingan umum, cinta tanah air, bangga menggunakan bahasa dan produk Indonesia, dinamis, kerja keras, dan beretos kerja. Keempat, olah raga yaitu bersih dan sehat, 
sportif, tangguh, andal, berdaya tahan, bersahabat, kooperatif, determininatif, kompetitif, ceria, ulet, dan gigih.

Yetri dan Firdaos Rijal (2017: 268) mengemukakan bahwa upaya-upaya penguatan terhadap pendidikan karakter, juga sudah lama dilakukan pemerintah, diantaranya dengan melakukan Gerakan Nasional Pendidikan Karakter Bangsa Tahun 2010 yang kemudian dilajutkan dengan program Penguatan Pendidikan Karakter (PPK) pada tahun 2016. Hal ini sesuai dengan salah satu butir Nawacita melalui Gerakan Revolusi Mental yang di maklumatkan presiden Joko Widodo.

Upaya-upaya penguatan terhadap pendidikan karakter, juga sudah lama dilakukan pemerintah, diantaranya dengan melakukan Gerakan Nasional Pendidikan Karakter Bangsa Tahun 2010 yang kemudian dilajutkan dengan program Penguatan Pendidikan Karakter (PPK) pada tahun 2016. Hal ini sesuai dengan salah satu butir Nawacita melalui Gerakan Revolusi Mental yang di maklumatkan presiden Joko Widodo. operasional pengembangan, pelaksanaan, dan penilaian pendidikan karakter. Sebagai tindak lanjut kebijakan tersebut, pemerintah telah merumuskan lima nilai utama karakter yang saling berhubungan membentuk jejaring nilai serta perlu dikembangkan sebagai prioritas gerakan PPK. Kelima nilai utama karakter bangsa tersebut adalah ; (1) relegius, (2) Nasionalis, (3) mandiri, (4) Gotong royong, dan (5) integritas.

Penguatan pendidikan karakter dapat dimaknai sebagai pengejawantahan Gerakan Revolusi Mental sekaligus bagian integral Nawacita. Gerakan PPK menempatkan pendidikan karakter sebagai dimensi terdalam atau inti pendidikan nasional sehingga pendidikan karakter menjadi poros pelaksanaan pendidikan dasar dan menengah. Lebih lanjut, Gerakan PPK perlu mengintegrasikan, memperdalam, memperluas, dan sekaligus menyelaraskan berbagai program dan kegiatan pendidikan karakter yang sudah dilaksanakan sampai sekarang. Dalam hubungan ini pengintegrasian dapat berupa pemaduan kegiatan yang ada didalam kelas, luar kelas, dan luar sekolah (masyarakat/komunitas); pemaduan kegiatan intrakurikuler, kokurikuler, dan ekstrakurikuler; pelibatan secara serempak warga sekolah, keluarga, dan masyarakat; perdalaman dan perluasan dapat berupa penambahan dan pengintensifan kegiatan-kegiatan yang berorientasi pada pengembangan karakter siswa, penambahan dan pemajanan kegiatan belajar siswa, dan pengaturan ulang waktu belajar siswa di sekolah atau luar sekolah; kemudian penyelerasan dapat berupa penyesuaian tugas pokok guru, Manajemen Berbasis Sekolah, dan fungsi Komite Sekolah dengan kebutuhan PPK.

Pengembangan atau pembentukan karakter diyakini perlu dan penting untuk dilakukan oleh sekolah untuk menjadi pijakan dalam penyelenggarakan pendidikan karakter di sekolah. Tujuan pendidikan karakter pada dasarnya adalah mendorong lahirnya anak-anak yang baik dengan tumbuh dan berkembangnya karakter yang baik akan mendorong peserta didik tumbuh dengan kapasitas dan komitmennya untuk melakukan berbagai hal yang terbaik dan melakukan segalanya dengan benar serta memilki tujuan hidup. Masyarakat juga berperan membentuk karakter anak melalui orang tua dan lingkungan.

Begitu pentingnya pendidikan karakter di negeri ini, untuk itu bagi kepala sekolah, pendidik maupun orang tua hendaknya senantiasa menanamkan karakter pada anak didiknya untuk membentuk watak dan peradaban bangsa yang bermartabat.

\section{Metode}

Jenis pendekatan yang digunakan penelitian ini adalah dengan metode kualitatif dengan pendekatan deskriptif. Desain penelitian yang digunakan oleh peneliti menggunakan tahapan penelitian menurut Moeloeng. Penelitian tentang Penguatan Pendidikan Karakter (PPK) ini dilaksanakan di SD Negeri Pandean Lamper 04 Semarang yang beralamatkan Jalan Banteng Utara VI, Kelurahan Pandean Lamper, Kecamatan Gayamsari, Kota Semarang, Jawa Tengah 50249. Peneliti memilih SDN Pandean Lamper 04 Semarang ini dikarenakan sudah melaksanakan Program Penguatan Pendidikan Karakter (PPK) mulai awal tahun 2018.

Subyek penelitian penelitian adalah siswa kelas V SD Negeri Pandean Lamper 04 Semarang. Data dalam penelitian ini diperoleh melalui observasi, wawancara, angket, dan 
dokumentasi. Peneliti melakukan observasi tentang sikap siswa saat kegiatan Penguatan pendidikan Karakter (PPK). Wawancara, dilakukan dengan Kepala Sekolah dan guru kelas V yang bertujuan untuk mengetahui permasalahan yang ada disekolah dasar.

Metode angket dengan memberikan tanda Check List, ditujukan untuk mengetahui karakter cinta tanah air siswa melalui kegiatan Penguatan pendidikan Karakter (PPK). Berikut tentang skor penelitian angket pembentukan karakter cinta tanah air melalui kegiatan Penguatan Pendidikan Karakter (PPK) yang digunakan;

Tabel 1. Skor penelitian angket pembentukan karakter cinta tanah air melalui kegiatan Penguatan Pendidikan Karakter (PPK)

\begin{tabular}{llcc}
\hline & No & Alternatif Jawaban & \multicolumn{2}{c}{ Skor Jawaban } \\
& & Pertanyaan (+) & Pertanyaan (-) \\
\hline 1 & Selalu & 4 & 1 \\
2 & Sering & 3 & 2 \\
3 & Kadang-Kadang & 2 & 3 \\
4 & Tidak Pernah & 1 & 4 \\
\hline
\end{tabular}

Dokumentasi bertujuan sebagai pendukung dan pelengkap bagi data-data yang diperoleh melalui observasi dan wawancara, alat yang digunakan berupa alat elektronik seperti kamera dan video.

Pada penelitian ini, peneliti menggunakan teknik Triangulasi. Triangulasi adalah teknik pemeriksaan keabsahan data yang memanfaatkan sesuatu yang lain. Triangulasi yang digunakan dalam peneliti ini adalah triangulasi metode. Teknik analisis data yang dipergunakan dalam penelitian ini menggunakan tahapan penelitian menurut Sugiyono6 yaitu teknik deskriptif dengan membuat gambaran yang dilakukan dengan cara; yang pertama pengumpulan data, yang kedua reduksi data, yang ketiga penyajian data, yang keempat kesimpulan. Teknik tahap penelitian yang dipergunakan dalam penelitian ini ada tiga yaitu tahap pralapangan, tahap pekerjaan lapangan, dan tahap analisis data..

\section{Hasil dan Pembahasan}

Tahap pertama yaitu melakukan studi pendahuluan melalui observasi, wawancara tujuannya untuk menemukan permasalahan terkait dengan nikai karakter siswa. Tahap selanjutnya yaitu Penelitian yang dilakukan di SDN Pandean Lamper 05 Semarang pada tanggal 19 - 27 Maret 2019 tentang Pembentukan Karakter Cinta Tanah Air Melalui Kegiatan Penguatan Pendidikan Karakter (PPK) Siswa Kelas V SDN Pandean Lamper 04 Semarang ini dibantu oleh partisipasi dari siswa kelas V, Guru kelas V dan juga Kepala Sekolah. Setelah itu pada akhir penelitian peneliti membagi angket kepada siswa kelas V SD Negeri Pandean Lamper 04 Semarang.

Penelitian ini dilakukan dengan melihat aspek-aspek di dalam indikator karakter cinta tanah air atau nasionalisme dalam proses Penguatan Pendidikan Karakter (PPK) dari berbagai sumber pengamatan, wawancara maupun hasil angket penulis dan informan dan responden.

Data yang peneliti dapatkan ketika pengamatan atau observasi dalam pelaksanaan Penguatan Pendidikan Karakter (PPK) semua elemen sekolah berperan aktif, terlihat guru memberikan arahan kepada siswa. Menurut hasil pengamatan peneliti pada saat kegiatan siswa kelas $\mathrm{V}$ sudah mulai terlihat perkembangan mengenai pentingnya kegiatan Penguatan Pendidikan Karakter (PPK) dalam meningkatkan nilai karakter.

Angket yang digunakan peneliti yakni angket yang sudah disediakan jawabannya sehingga siswa tinggal memilih salah satu jawaban yaitu "selalu, sering, kadang-kadang, dan tidak pernah". Respon dalam angket ini adalah seluruh siswa kelas V SDN Pandean Lamper 04 Semarang. Pada penelitian ini peneliti menerapkan lima indikator karakter cinta tanah air atau nasionalisme. 


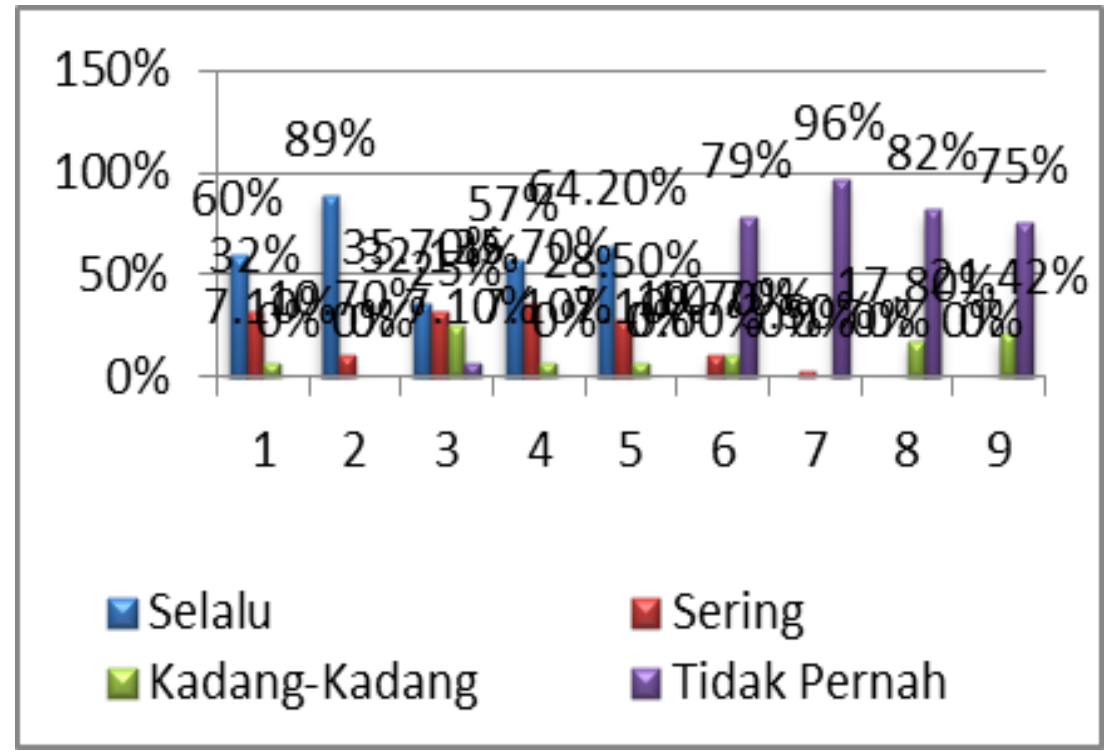

Gambar 1. Hasil Angket pada lima Indikator Cinta Tanah Air (Nsionalisme) 1-9

Pada indikator yang pertama yaitu menghargai jasa para tokoh/ pahlawan nasional terdapat pada pernyatan no 1-5 (Positif) dan 6-9 (negatif).

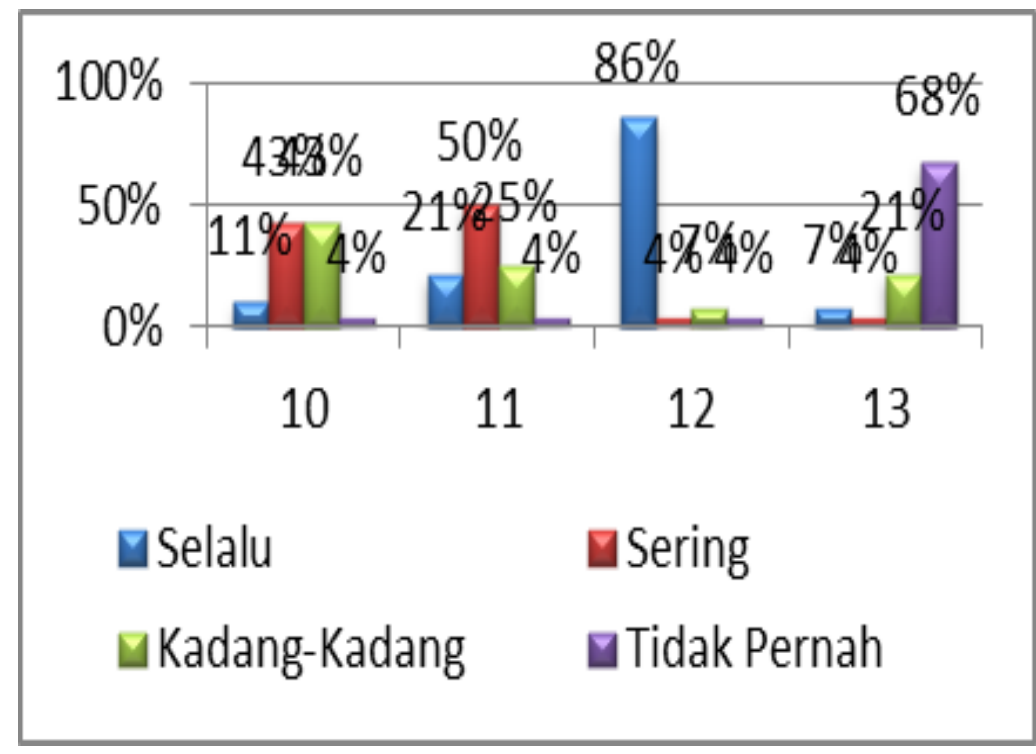

Gambar 2. Hasil Angket pada lima Indikator Cinta Tanah Air (Nsionalisme 10-13

Pada indikator yang kedua yaitu bersedia menggunakan produk sendiri terdapat pada pernyataan no 10-12 (Positif) dan 13 (negatif). 


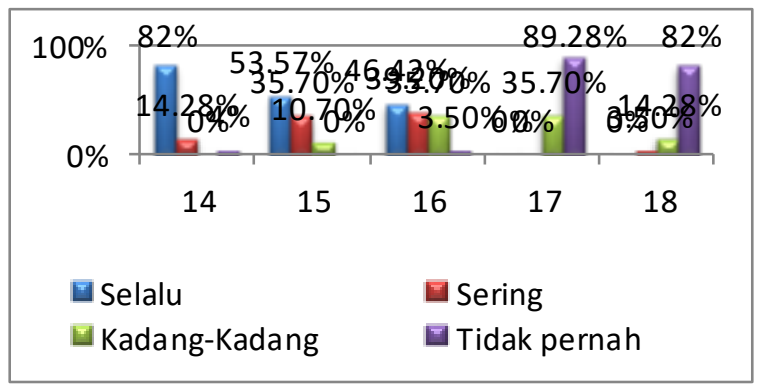

Gambar 3. Hasil Angket pada lima Indikator Cinta Tanah Air (Nsionalisme) 14-18

Pada indikator yang ketiga yaitu Menghargai Keindahan Alam dan Budaya Indonesia terdapat pada pernyataan nomor 14-16 (Positif) dan 17-18 (negatif).

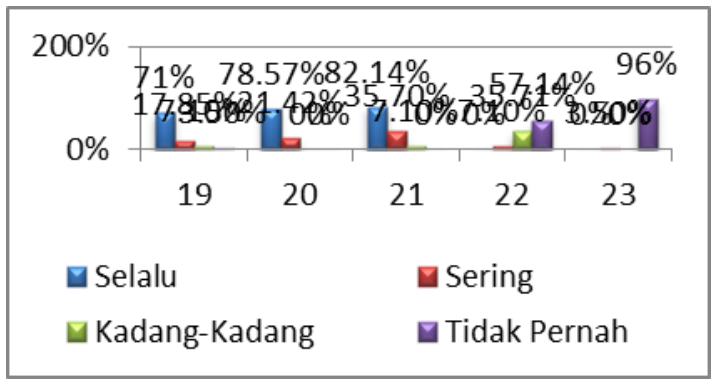

Gambar 4. Hasil Angket pada lima Indikator Cinta Tanah Air (Nsionalisme) 19-23

Pada indikator yang ketiga yaitu lagu-lagu kebangsaan terdapat pada pernyataan nomor 19-21 (Positif) dan 22-23 (negatif).

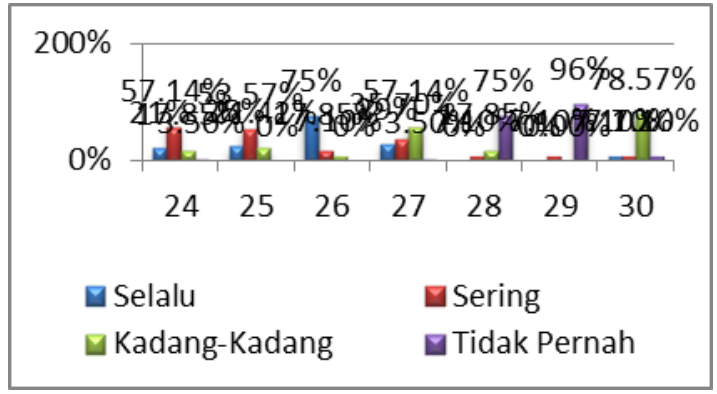

Gambar 5. Hasil Angket pada lima Indikator Cinta Tanah Air (Nsionalisme) 24-30

Pada indikator yang ketiga yaitu memilih berwisata dalam negeri sendiri terdapat pada pernyataan nomor 24-27 (Positif) dan 28-30 (negatif). Berdasarkan pengamatan peneliti, guru dalam memberi arahan kepada peserta didik dan juga sebagai model pendidikan karakter guru sudah berperan dengan secara maksimal, peran guru dalam meningkatkan nilai-nilai karakter dengan memberi contoh dan arahan yang nantinya dicontoh oleh peserta didik. Peneliti juga mengamati upaya-upaya Kepala Sekolah dan Guru lakukan sebagai model pendidikan karakter, peran Guru sebagai model pendidikan karakter dalam hal ini sudah sesuai dengan apa yang diharapkan dan juga diteladani bagi peserta didik kelas V di SDN Pandean Lamper 04 Semarang. 


\section{Simpulan dan Saran}

Berdasarkan hasil penelitian mengenai pembentukan karakter cinta tanah air melalui Penguatan Pendidikan Karakter (PPK) siswa kelas di SDN Pandean Lamper 04 Semarang maka dapat disimpulkan sebagai berikut : (1) Kegiatan Penguatan Pendidikan Karakter (PPK) yang dilaksanakan di SDN Pandean Lamper 04 Semarang sudah berjalan dengan cukup baik, hal ini dapat dilihat dari perkembangan karakter siswa yang sudah meningkat lebih baik. (2) Dari data hasil angket yang telah diisi oleh responden dapat dilihat hasil tertinggi sebesar $96 \%$ yaitu siswa menjawab "Tidak Pernah" pada pernyataan ke 7,23, dan 29 (negatif).

\section{Daftar Pustaka}

Andiarini,E,S,dkk.2018.Implementasi ProgramPenguatan Pendidikan Karakter Melalui Kegiatan Pembiasaan Dalam Peningkatan Mutu Sekolah.Jurnal Administrasi dan Manajemen Pendidikan.Universitas Negeri Malang.

Daryanto.,Suryatri Darmiatun.,2013.Implementasi Pendidikan Karakter di Sekolah.Yogyakarta:Penerbit Gava Media.

Dharma,K.,Cepi,T.,Johar Permana.2013.Pendidikan Karakter Kajian Teori dan Praktik di Sekolah.BANDUNG: PT Remaja Rosdakarya.

Mulyana, H. E.,2011.,Manajemen Pendidikan Karakter.

Mustari,Mohamad.,2017.Nilai Karakter Refleksi Untuk Pendidikan.Depok:PT Rajagrafindo Persada.

Moleong Lexy J.,2017.Metodologi Penelitian Kualitatif.Bandung:PT Remaja Rosdakarya.

Noor M Rohinah.2012.Mengembangkan Karakter Anak Secara Efektif di Sekolah dan di Rumah.Yogyakarta;PT Pustaka Insan Madani.

Subadar.2017.Penguatan Pendidikan Karakter (PPK) Berbasis HIGHEER Order Thinking Skills (HOTS).Jurnal Pedagogik. Pengawas Pendidikan,Kantor Kementerian Agama,Kabupaten Purbalingga.

Undang-Undang Republik Indonesia, No. 20 Tahun 2003 tentang Sistem Pendidikan Nasional.

Wibowo,Agus.,2012.Pendidikan Karakter Strategi Membangun Karakter Bangsa Berperadaban.Yogyakarta:Pustaka Pelajar.

Yetri,Rijal Firdaus.2017.Penguatan Pendidikan Karakter Berbasis Masyarakat Pada Sekolah Menengah Pertama Negeri (SMPN) di Kabupaten Tulang Bawang Provinsi Lampung.Jurnal Pendidikan Islam.Universitas Islam Negeri Raden Intan Lampung. 